\title{
Customer Relationship Management Practices of Megamart in the Kingdom of Bahrain
}

\author{
Fatema Fuad Almansoori \\ MBA Student, AMA International Univeristy Bahrain \\ Surjit Victor \\ Assistant Professor, AMA International Univeristy Bahrain
}

\begin{abstract}
The study aims to assess Customer Relationship Management (CRM) practices of MegaMart in the Kingdom of Bahrain. In this research, to adequately address the research questions, a variety of data collection methods and instruments were used and done by conducting an empirical investigation into Customer Relationship Management (CRM), an adoption behavior of 15 branches of MegaMart in the Kingdom of Bahrain. The purpose of the study was to evaluate the Customer Relationship Management (CRM) practices of MegaMart in the Kingdom of Bahrain. The effectiveness of Customer Relationship Management (CRM) was conducted through a survey, using the questionnaire as the research instrument. The respondents of the study are employees and customers of MegaMart in the Kingdom of Bahrain. The research instrument used the five-point Likert Scale. The statistical tools utilized in the study are multiple regression analysis and weighted mean. The study provides recommendations by the researcher in assessing those questions around Customer Relationship Management (CRM) methods in the Kingdom of Bahrain. Customer Relationship Management (CRM) can be applied as a tool to enhance the practices of MegaMart in the Kingdom of Bahrain. From the study, the researcher concluded that Customer Relationship Management (CRM) findings further depict managerial implications and opportunities for future research in the same area.
\end{abstract}

Keywords: Customer Relationship Management, MegaMart in the Kingdom of Bahrain, practices

DOI: $10.7176 / \mathrm{EJBM} / 12-12-07$

Publication date: April $30^{\text {th }} 2020$

\section{Introduction}

The conception of Customer Relationship Management (CRM) has emerged within the selling literature by stimulating the interest of the educational community. It involved the combination of provide-chain functions to attain a more considerable potency in delivering and up-to customer worth that represents a desirable domain within which to research the management of customer relationships. Thanks to its specific options of short-life cycle product, volatile demand, and high level of an impulse purchase. To grow within the future, quick fashion corporations trot out a good vary of data to develop a decent understanding of market trends, heretofore. Customer Relationship Management (CRM) is a professional practice to move beyond increasing the capacity of transactions in the organization. The purpose is to improve customer's profit, financial gain, and satisfaction. As a result, Customer Relationship Management (CRM) practices, an outsized set of tools, the technologies, and the company procedures help to stimulate the relationships with the consumer to increase the percentage of the sale. Consequently, CRM is mainly operative strategy and away from the purpose of scan rather than a technical read purpose. Customer Relationship Management (CRM) practices, its strategy, which is used daily to originate and maintain long term relationships with profitable customers (Lee 2018).

A productive start for Customer Relationship Management (CRM) practices initiates from a business plan and philosophy that keeps the attention of the company activities on what the customer wants. Customer Relationship Management (CRM) practices technology was thought to be a supportive matter for processes that lead the methods to business. Structure parts of Customer Relationship Management CRM practices were ingrained into three elements: Customer, Relationship, and Management. Customer Relationship Management (CRM) is perceived as a feature amongst the best methodologies in accomplishing objectives of customer fulfillment and dependability. In any case, there were conflicting views in writing regarding the adequacy of Customer Relationship Management (CRM) rehearses, customer's attainment retaining and development, while at the same time it is supporting the broader of the organizational goals (Buttle \& Maklan 2015). Customer Relationship Management (CRM) was not limited to the marketing section of the organization. It included property integrated development within the organization's culture and practices.

Customer Relationship Management (CRM) is an approach used by the corporate marketing department to manage the relationship between the brand and existing and targeted customers. Individual customers may be of different characteristics and may mean companies that were dealt with based on their legal personality. Relationship management can also be referred to as automated systems that analyzed audience marketing activities and their relationship to the brand. In both cases, the human and automated concept shared a single mission: to 
improve the way we communicate with the target customer and give them the best purchasing experience possible (Ashraf et al., 2017: Akram, Murugiah, and Arfan, 2017: Abrar ul haq et al., 2017a,b)..

Customer Relationship Management (CRM) systems aggregated all old and young customers, ranging from personal data such as age, social, and physical level, to the study of their psychological characteristics and their various interactions with messages addressed to them. This information acted as the cornerstone of marketing activities as a whole. Without it, marketing campaigns cannot achieve their goals with the required efficiency, and without them, the company cannot communicate with their current audience or attract more target audiences.

Before the 1990s, there was no transparent system for managing these relationships. The task of understanding the customer was the impediment of the staff in the public relations department. But with the emergence of the Internet and the expansion of companies at the regional and international level, the task of relationship management has become a responsibility assumed by modern CRM applications, regulating the relationship between companies and their diverse audience, and illustrate the most effective ways to influence their preferences and heterogeneous tendencies (Khan et al., 2015; Mehtab et al., 2012; Merrilees \& Miller 2015).

Customers tried to send their opinion and send their messages, which was completely different from the entire owner's words. Usually, costumers tried to communicate by using social media; for example, they will use Facebook and Twitter. Customer Relationship Management (CRM) was created to make sure of the advances in the data technology, notably the facility, to collect, save, understand, and distribute the information related to the customer. The organizations created their relationship management strategies. Applying CRM usually depended on the utilization of structured data related to customers and partners that are saved in the databases of the company (Ullah et al., 2016; Buttle \& Maklan 2015).

A comprehensive analysis study directed by Gartner in 2015, uncovered that half of all actual Customer Relationship Management (CRM) comes in neglecting to fulfill needs (Qamri et al, 2015; Qasim et al., 2018; Razaet al., 2018). Several theorized that innovation was driving the Customer Relationship Management (CRM) systems as hostile. A distinct manner, incontestable that few had modified once they elaborate that $47 \%$ of Customer Relationship Management (CRM) was missing the mark regarding achieving the objectives set by Customer Relationship Management (CRM) procedures. Viable Customer Relationship Management (CRM) relied upon quality customer correspondence. Without customized communications with customers, organizations will battle to market, sell, or bolster customers. Customers expected Customer Relationship Management (CRM) frameworks to be able to rapidly get to a 360-degree customer view to give productive and viable interchanges. More roads of correspondence were accessible to achieve customers than at any other time. Organizations that created Customer Relationship Management (CRM) systems that contacted customers in the manner by which they need to be reached will acknowledge achievement (Merrilees \& Miller 2015).

Customer Relationship Management (CRM) and customer reliability: The appearance of innovations prompted a move from Customer Relationship Management (CRM) to e-Customer Relationship Management (CRM). With expanding worldwide entrance of the web, e-Customer Relationship Management (CRM) turned into a progressively famous specialized apparatus and relationship-building stage. Not surprisingly, customer loyalty was a commonly implemented CRM practice across several industries (Nguyen, Simkin \& Canhoto, 2019). We can say that CRM implementation and strategy is successful only if it can improve customer loyalty to the company (Skoumpopoulou \& Franklin, 2019).

Loyal customers were the most valuable for the company in rising profit-making. To be able to get some loyal customers, they emphasized the importance of catching the new customers and retain them, a high commitment in terms of funds and human resources to get a good product quality that matches the costumers' needs (Budianto, 2019).

A study of Nguyen et al., (2019) on e-Customer Relationship Management (CRM) suggests that e-CRM helps to get profitable customers to stay faithful, since data put away in the e-Customer Relationship Management (CRM) practices help an association to take a gander at the real expense of pulling in and holding customers. Most CRM practices typically directed at retaining all customers of the firm. Moreover, CRM practices helped customers to pursue and spread positive verbal exchange about the administration and the supplier, which in general outcome prolong relationships, trust, and promise to the specialist co-op in that capacity. Customers were more likely to give positive referrals to the firm' s products and services to other potential customers.

\section{Statement of the Problem}

Customer communication needed to be improved. The customer needed to be connected to the management in terms of receiving complaints and suggestions. Receiving information enhances the CRM on the quality of the service and the product provided to the customer. On the other hand, to implement the CRM on MegaMart properly, we had to study the personal customer behavior because this fact had a significant effect on the CRM in terms of deciding the required decision on the promotion and discount. MegaMart has an outstanding amount of customers for the past years; however, during the summer season, sales tend to go down. Moreover, some customers had a problem with not having a delivery system in MegaMart as same as the remain retail stores and no assistant to the 
customer when it requires it (Bahrain Chamber of Commerce and Industry, 2018).

Therefore, MegaMart faced tough times in the last two to three years. Small coldstores have opened and providing this service, and that was affecting the loyalty of the customer and when you have less commitment that will affect CRM in terms of the number of sales.

Based on the questions as mentioned above, this study aimed mainly on how Customer Relationship Management (CRM) has an effect on MegaMart in the Kingdom of Bahrain practices on customers, that will help with communication, loyalty, and attitude on marketing. For this, the study established the following objectives:

1. To analyze the effect of Communication on Customer Relationship Management (CRM) practices of MegaMart in the Kingdom of Bahrain.

2. To analyze the effect of Loyalty on Customer Relationship Management (CRM) practices of Meganart in the Kingdom of Bahrain.

3. To analyze the effect of Attitude on Customer Relationship Management (CRM) practices of MegaMart in the Kingdom of Bahrain.

4. To bring out the most crucial factor that influences on Customer Relationship Management (CRM) practices of MegaMart in the Kingdom of Bahrain.

\section{Research Hypothesis}

1. There is no significant effect of Communication on Customer Relationship Management (CRM) practices of MegaMart in the Kingdom of Bahrain.

2. There is no significant effect of Loyalty on Customer Relationship Management (CRM) practices of MegaMart in the Kingdom of Bahrain.

3. There is no significant effect of Attitude on Customer Relationship Management (CRM) practices of MegaMart in the Kingdom of Bahrain.

4. There is no significant relationship between communication, loyalty, and attitude as a whole and Customer Relationship Management practices of MegaMart in the Kingdom of Bahrain.

\section{Significance of the study}

The study provided the Researcher and MegaMart a broader interpretation and identify practical solutions to its Customer Relationship Management practices. It aided the Marketing Department in recognizing critical areas in customer service, in general. The study was essential for companies such as MegaMart in the Kingdom of Bahrain as it helped to understand the need of customers by using this strategy; transactions that involved services, marketing, and sale of products to the customers can be transmitted out regularly and systematically. Moreover, they improved their services that applied to customers by understanding their issues, which helped to increase customer loyalty. In this way, the company got continuous feedback from the customers regarding both the products and services. It was an effective way that gave the customers the ability to provide their recommendations to the company, which delivered effectiveness and satisfactory about the services. Customer Relationship Management (CRM) practices helped the customers to determine the quality of the services and products which are given by the organizations. It led to the satisfaction of customers and helped the business to develop. This study contributed to enhancing the knowledge regarding the marking field (related to food \& nonfood). Moreover, it showed that to activate the strategy of focusing on the customers, and they should give exceptional service for the customers; for example, there was continuous contact between the company (MegaMart) and their customers. It helped employees of the company to give the best service to loyal customers, which increased the amount of satisfaction of the customers. The company kept and retained its customers. Furthermore, it improved and developed Customer Relationship Management (CRM) practices in the Kingdom of Bahrain.

\section{Conceptual Framework}

The conceptual framework of the study developed based on the theoretical framework, and the statement of the problem addressed. The study developed a conceptual framework based on the identified factors of Customer Relationship Management (CRM) practices in MegaMart in the Kingdom of Bahrain. The conceptual framework measured the influence of independent variables on the dependent variable. The dependent variable was the overall effectiveness of Customer Relationship Management (CRM) practices, and the independent variables were market segmentation, targeting, and positioning. It is shown in the diagram below.

(Figure 1.4) 


\section{INDEPENDENT VARIABLES}

\section{DEPENDENT VARIABLES}

\begin{tabular}{|c|c|}
\hline Communication & $\begin{array}{c}\text { Customer } \\
\text { Relationship } \\
\text { Management } \\
\text { (CRM) }\end{array}$ \\
\hline Attitude & \\
\hline
\end{tabular}

Figure1: Conceptual Framework

The framework illustrates the variables in which the overall effectiveness of Customer Relationship Management (CRM) is measured. The process focuses on how the independent variables will affect the dependent variable.

\section{Scope and Limitation of the Study}

The scope of this study determined the level of effectiveness of Customer Relationship Management (CRM). The study was limited only to the 15 branches in the Kingdom of Bahrain. The limitations possibly encountered during this study were:

- The survey conducted might not be thought-about as comprehensive as solely restricted respondents may be contacted owing to the time constraint.

- Some of the respondents might be reluctant to give their responses.

- Since the research design was descriptive, the opinion of the respondents can change after the period of study.

- The marketing information and actual real-time data were not available to the researcher from MegaMart, as it was confidential.

\section{LITERATURE REVIEW}

Matthews (2017) studied the various segments; each factor is exceptional in itself and acts as a remarkable job during the time spent Customer Relationship Management (CRM) to run an association towards progress examination and friends' destinations. SalesForce Automation is utilized by business establishing, for instance, anticipating, recording deals preparing just as monitoring the plausible cooperation's. Additionally, it knows the salary age openings better, and that makes it significant. Deals Force Automation incorporates expecting, recording deals handling, and following potential collaborations. Management could be a purposive activity. It is one thing that directs cluster efforts towards the attainment of predetermined bound goals. The writing survey has been created captivated with factors of this exploration suppose, for instance, dangers and task the executive's procedure. Numerous components of writing surveys are cared-for captivated with the applied system as for shopper relationship; the executives perform in MegaMart within the Kingdom of Bahrain. From there on, ideas of shopper relationship the board practices procedure are shown and processed. Furthermore, this writing audit has unconcealed insight into the theoretical delineation of analysis factors the method of operating with and through others to effectively win the goals of the organization by expeditiously mistreatment limited resources within the changing world. Of course, these goals might vary from one enterprise to a different (Akram et al., 2019; Akram, 2017).

Lee (2018) covered all the aspects that should be taken among the adoption of shopper relationship management (CRM terms of a strategic perspective). In this study, they were analyzing 32 models in between 1999 and 2015, to help the authors to get the components internal to the structure which is characterized in six parts: CRM strategy formulation relative, merchandising philosophy, the way of applying the best practices, structure and human resources processes of CRM and finally CRM technology. It is to presents the definition of CRM that includes these dimensions and considering the most purposeful areas to operate the CRM, which is: merchandising, sales, and repair.

The definition and perspective of association dimensions developed on the described of each of the sizes, and the authors tried to give the abstract model for the adoption of Customer Relationship Management (CRM) can increase business performance and gain more competitive advantage.

A read through the eyes of customers, Muhammad Hasan Galib, Alliant International University, USA, 'said 
that to understand the social customer's behavior, they should find the factors that influence the customer's decision to engage in social Customer Relationship Management (CRM) programs. Lee (2018) developed the social, behavioral model (SBM) in this study. The event of the SBM has divided into these points: the stylish model's technology, the acceptance model, and finally, the theory of planned behavior Malik, et al., (2014, 2017a,b\&c, 2018, 2019a,b\&c).

They were analyzing the data with beta multivariate analysis, collateral multivariate analysis and path analysis, attitude, usefulness, and perceived risk are the most critical factors in SBM. However, other variables were less critical, like perceived simple use, perceived activity affected intention management, perceived enjoyment, and indirect satisfaction. Subjective norms and images do not affect intention directly or indirectly; so, those variables were created from the SBM. The theoretical framework results in providing a stronger notional basis to understand the activity portion of social CRM implementation. It is changed from Shopper Relationship Management into Influencer Relationship Management (Lee 2018).

Atton Institute (2018) was the most attractive in marketplaces food outlets with vegetables, exotic fruits, and pastries, consumer goods, and numerous textiles depicted the second branch of interest for purchasers. It is another powerful switch that improved business management and client services. Technology's impact on the market decision centers appeared around the sixties and was an accustomed answer and resolved client problems. Some years later, the primary email system became practical, and shortly the wide globe net had accurately revolution the business setting. Customers currently have instant access to merchandise.

Rigby et al. (2019). Most huge, it has been detected that there is strikingly poor business execution from Customer Relationship Management (CRM). Earlier advertising exploration demonstrates that Customer Relationship Management (CRM) applications are not consistently conveying anticipated business upgrades and that the issue could come from issues, for example, nonappearance of client courses. Not at all like numerous other corporate rules, Customer Relationship Management (CRM) centered around the customer and customer relationships as opposed to deals or benefits. Customer Relationship Management (CRM) utilized likewise in the business-to-buyer zone. However, it assumed a reasonably extraordinary job here because Customer Relationship Management (CRM) for business customers founded typically on procedures and arrangements that customized explicitly to singular customers.

\section{METHODOLOGY OF THE STUDY}

The study performed the research strategy of a questionnaire survey on Customer Relationship Management (CRM) practices of MegaMart in the Kingdom of Bahrain. The segment further hoisted the answers for Customer Relationship Management (CRM) practices of the Kingdom of Bahrain. As indicated by Saunders, inquire about is characterized as "the orderly gathering and understanding of data with an apparent reason, to discover things out. When leading exploration, two methodologies can be utilized: Quantitative and Qualitative. Quantitative research techniques generally include enormous randomized examples, more utilization of measurable, and a couple of uses of cases showing discoveries. The examination for this study was directed through writing audit, with no observational work being led. A massive asset of composed material was utilized, which included books, magazine articles, academic diaries, just as the sites of different organizations. Slovin's Formula was quite popularly used in the Kingdom of Bahrain for determining the sample size for survey research, especially in undergraduate thesis in education and social sciences, maybe because it was easy to use, and the computation was based on almost solely on the population size. The Slovin's Formula is given as follows: $n=N /(1+N e 2)$, where $n$ is the sample size, $\mathrm{N}$ is the population size, and $\mathrm{e}$ is the margin of error to be decided by the researcher. However, its misuse was now a popular subject of research here in the Kingdom of Bahrain, and students were usually discouraged from using the formula even though the reasons behind are not clear enough to them. Perhaps it will help if we could know who was Slovin and what were the bases of his formula.

Customer satisfaction measurement exercise provided information about the priority of the customers, as well as the company performance having the concern about how to design the customer survey to be accurate. It was based on understanding the details of the customer and the company relationship and the customers' buying behavior. It usually needed exploratory research that made sure survey covered all the factors which make the best contribution to customer satisfaction instead of the issues in which the company thinks essential. The company implemented a customer survey professionally to produce reliable data for decision making. The most crucial aspect that helped in distinguishing a professional from the survey was the sampling. Accurate sampling was essential to show that the survey was based on a representative group of customers. Besides, for the review, we chose an example of all-out respondents from the MegaMart in the Kingdom of Bahrain company, in which 20 respondents were the staff, and the rest of the 80 respondents were the customers. The researcher chose 150 respondents from which 30 were incorrect, and 20 were canceled due to incompletion. There were 100 respondents of the sampling size. 
Table 1: Respondents of the Study

\begin{tabular}{lll}
\hline Respondents & Population & Percentage \\
\hline MegaMart in the Kingdom of Bahrain-Muharraq & 11 & $11 \%$ \\
MegaMart in the Kingdom of Bahrain-Galali & 11 & $11 \%$ \\
MegaMart in the Kingdom of Bahrain-Soqaiya & 11 & $11 \%$ \\
MegaMart in the Kingdom of Bahrain-Lulu Manama & 11 & $11 \%$ \\
MegaMart in the Kingdom of Bahrain-Al Juffair & 11 & $11 \%$ \\
MegaMart in the Kingdom of Bahrain-Saar & 11 & $11 \%$ \\
MegaMart in the Kingdom of Bahrain-Amwaj & 11 & $11 \%$ \\
MegaMart in the Kingdom of Bahrain-Riffa & 11 & $11 \%$ \\
MegaMart in the Kingdom of Bahrain-Budaiya & 12 & $12 \%$ \\
Total & 100 & $100 \%$ \\
\hline
\end{tabular}

\subsection{Research Instruments}

The examination technique includes the strategies that were utilized by the scientist for the fruition of an exploration venture. The exploration procedures contain a contextual investigation system and review methodology.

The procedure managed the gathering of data from exact sources. Besides, it expressed the scientists to remove the required data to utilize the exploration methodologies. Study procedure, for example, empowers the scientists to get data from an enormous number of respondents while the exploratory technique was used in situations where new speculations and models that bear significance to the theme of the examination were given.

Below gave some statements that measured Customer Relationship Management (CRM) practices of MegaMart in the Kingdom of Bahrain. Kindly circle your agreement level in a 5-point scale, where 5 stands for strongly agree, 4 agree, 3 neutrals, 2 disagree, and 1 strongly disagree. There is no right or wrong answer; state your opinion.

Table 2: Autocratic Customer Relationship Management Style Survey

\begin{tabular}{|c|c|c|}
\hline $\begin{array}{c}\text { Item } \\
\text { no. }\end{array}$ & Autocratic Customer Relationship Management Style & Reference \\
\hline 1 & All people in my MegaMart treat customers with great care. & \\
\hline 2 & Efforts are made by employees to make the customer delighted. & Hill \& \\
\hline 3 & MegaMart treats its customers with respect. & Alexander \\
\hline 4 & $\begin{array}{l}\text { MegaMart offers convenience to its customers (e.g., online services, home delivery, } \\
24-7 \text { customer service). }\end{array}$ & (2017). \\
\hline 5 & MegaMart solves problems efficiently. & \\
\hline \multicolumn{3}{|c|}{ Autocratic Communication Style } \\
\hline 1 & $\begin{array}{l}\text { MegaMart encourages interaction among its customers (e.g., events, Facebook, } \\
\text { etc.) }\end{array}$ & \multirow{5}{*}{$\begin{array}{l}\text { Hill \& } \\
\text { Alexander } \\
\text { (2017). }\end{array}$} \\
\hline 2 & $\begin{array}{l}\text { MegaMart has communication channels for complaints and suggestions (e.g., toll- } \\
\text { free, online customer service, etc.). }\end{array}$ & \\
\hline 3 & MegaMart tries to get to know my preferences, questions, and suggestions. & \\
\hline 4 & Our staff is competent in handling customer concerns. & \\
\hline 5 & MegaMart has the right virtual, in case of websites). & \\
\hline \multicolumn{3}{|c|}{ Autocratic Loyalty Style } \\
\hline 1 & I feel I am loyal to MegaMart's brand/offerings. & \multirow{5}{*}{$\begin{array}{c}\text { Hill \& } \\
\text { Alexander } \\
\text { (2017). }\end{array}$} \\
\hline 2 & $\begin{array}{l}\text { Even when I hear negative information about MegaMart, I still stick with } \\
\text { MegaMart. }\end{array}$ & \\
\hline 3 & Even with more choices, I will not choose other brands/offerings. & \\
\hline 4 & My continued association with MegaMart is essential to me. & \\
\hline 5 & $\begin{array}{l}\text { if I've been asked to change to another supermarket, I would still choose and } \\
\text { promote MegaMart. }\end{array}$ & \\
\hline \multicolumn{3}{|c|}{ Autocratic Attitude Style } \\
\hline 1 & I feel good when I enter MegaMart. & \multirow{5}{*}{$\begin{array}{c}\text { Am. J. Applied } \\
\text { Sci., } 3 \text { (4): } \\
\text { 1814-1818, }\end{array}$} \\
\hline 2 & My shopping experiences with MegaMart are better than I expected. & \\
\hline 3 & I will try new services and products that are provided by MegaMart. & \\
\hline 4 & I will recommend other people to patronize to MegaMart. & \\
\hline 5 & I will say positive things to other people about the services provided in MegaMart. & \\
\hline
\end{tabular}




\section{Data Gathering Procedure}

The information accumulation strategies were critical criteria that must be considered by the analysts to make an overall structure for an examination. The information-gathering strategies enabled the analyst to decide the precise assets required regarding finishing the methods of collecting data. For this particular research, the data were acquired by utilizing the study poll strategy, which fused the Likert scale noting strategies to present shut end inquiries to the respondents. The inquiries were given to the respondents online, which enabled the scientist to obtain vital data inside a limited ability to focus time. The data that were gathered by the scientist by applying this particular technique empowered the specialist regarding acquiring quantifiable outcomes. The informationgathering strategy was picked by scientists to further encourages examination of the data as the data was introduced as figures and numbers See also: (Abrar ul haq et al., 2012, 2015, 2016, 2018a,b \& 2019a,b; Abrar ul haq and Jali, 2016).

\section{Validity and Reliability}

First, to evaluate the reliability factor of the questionnaire, Alpha-Cronbach was used with a minimum value of 0.7, which was acceptable in the research field. Secondly, the reliability coefficient was tested with Pearson's Correlation between the scores. The value for a Pearson's coefficient can fall between 0.00 (no correlation) and 1.00 (perfect correlation). In this examination, the specialist collected the essential quantitative information from the review polls. These were accessible to the specialist in numerical figures. The scientist used tables to distribute the reactions as per the system of the inquiries. At last, these digits were changed to reaction rates, and a special section of reaction recurrence was displayed in the exploration.

\section{Data Process and Statistical Treatment of the Data}

After the inevitable strategy, it was proposed that the scientist inferred a particular procedure for everything about wanted strategy for the exploration. These were suggested by the specialist to meet the goals of the exploration and the examination questions proficiently. Furthermore, various information was gathered by the specialist. It was depicted and investigated in the segment given underneath. This factual device spoke to in scales that were utilized to quantify the connection between the jobs of Customer Relationship Management (CRM) practices of MegaMart in the kingdom of Bahrain and the effect between Customer Relationship Management (CRM) practices of MegaMart in the Kingdom of Bahrain.

\section{RESULTS AND DISCUSSION}

The chapter presented the research findings attained from the questionnaire.

The data of this questionnaire were collected by surveying, which was distributed in 15 branches to 100 random customers in MegaMart. The following tables presented the answers of the respondents of the survey, and it was statistically examined to test the relationship between the practices communication, loyalty, and attitude to identify essential practices that in Customer Relationship Management. These findings helped to achieve the objectives of the study. The data collected from 100 respondents from the 15 branch of MegaMart in the kingdom of Bahrain. The questionnaire contained general data of the respondents such as gender, age, shopping frequency, spending amount, product purchased, and monthly income. Moreover, it contained other parts of communication, loyalty, attitude, and Customer Relationship Management. Based on those respondents, the data was analyzed in the next section.

\section{Analysis of Data}

The section contained the analysis of the data in regards to the questionnaire and questionnaire participants. The analysis was based on 100 respondents of the MegaMart in Bahrain. The undertaken analysis divided the respondents into gender, age, shopping frequency, spending amount, product purchased, and monthly income. Table 3: Classification of Age Group

\begin{tabular}{lccc}
\hline \hline Age & Count of Age & \% of Age & Total \\
\hline $16-19$ & 5 & $6.60 \%$ & \\
$20-29$ & 33 & $31.30 \%$ & \\
$30-39$ & 50 & $50 \%$ & \\
$40-49$ & 9 & $10.60 \%$ & 100 \\
50 and above & 3 & $3.30 \%$ & 100 \\
\hline \hline
\end{tabular}

\section{Demographic Analysis}

The table presented an analysis of the demographic pattern of respondents. Table 4.1 summarized the details of the demographic profiles of the respondents. As shown in the table, $6.60 \%$ of the respondents were from the age group 16-19, 31.30\%of the respondents were from the age group $20-29,50 \%$ of the respondents were from the age 
group 30-39, and only $9 \%$ of the respondents were from the age group 40-49. The majority of respondents were from the age group of 30-39, which indicated that the respondents of the MegaMart customers were aged between 30 and 39 years old by $50 \%$, followed by 20 to 29 years old customers by $33.3 \%$.

Table 4: Gender

\begin{tabular}{lrcc}
\hline \hline Gender & Count of Gender & \% of Gender & Total \\
\hline Male & 34 & $30 \%$ & \\
Female & 66 & $70 \%$ & 100 \\
\hline \hline
\end{tabular}

\subsubsection{Gender}

Meanwhile, Table 4.2 showed the gender of the respondents. Where the majority of the participants were females as the percentage of the female respondents scored $70 \%$, while the male's percentage was $30 \%$.

Table 5: Monthly Income

\begin{tabular}{lccc}
\hline \hline Monthly Income & Count of Monthly Income & \% of Monthly Income & Total \\
\hline $0-100$ BD & 8 & $7.60 \%$ & \\
$100-250$ BD & 4 & $2.60 \%$ & \\
$250-500$ & 17 & $21.60 \%$ & \\
$500-1000$ & 48 & $48.30 \%$ & 100 \\
1000 and above & 23 & $22.60 \%$ & 100 \\
\hline \hline
\end{tabular}

The survey recorded that the mass majority of the customer's income exceeds 500 BHD.

Table 6: Product Purchased

\begin{tabular}{lccc}
\hline \hline Product Purchased & Count of Product Purchased & \% of Product Purchased & Total \\
\hline Food & 83 & $88.30 \%$ & 100 \\
Non-Food & 17 & $12.60 \%$ & 100 \\
\hline \hline
\end{tabular}

The survey recorded that most of the customers do their groceries from the supermarket mainly to buy food products.

Table 7: Shopping Frequency

\begin{tabular}{lccc}
\hline \hline Shopping Frequency & Count of Shopping Frequency & \% of Shopping Frequency & Total \\
\hline Weekly & 33 & $30.60 \%$ & $67 \%$ \\
Monthly & 59 & $0 \%$ & 100 \\
Yearly & 0 & $3.30 \%$ & \\
Rarely & 8 & & \\
\hline \hline
\end{tabular}

The survey showed that most of the customers do their shopping every month.

Table 8: Spending Amount

\begin{tabular}{lccr}
\hline \hline Spending Amount & Count of Spending Amount & \% of Spending Amount & Total \\
\hline Less than 10BD & 15 & $14.70 \%$ & \\
$10-20$ BD & 10 & $9.30 \%$ & \\
$20-50$ BD & 15 & $14.70 \%$ & \\
$50-100$ BD & 50 & $54 \%$ & 100 \\
100 BD and above & 10 & $9.30 \%$ & \\
\hline \hline
\end{tabular}

The survey recorded most of the spending amount is between 50 and $100 \mathrm{BHD}$, with $54 \%$ of the sample selected.

Table 9: Product and offers Awareness

\begin{tabular}{llcccccc}
\hline $\begin{array}{l}\text { Product and } \\
\text { Awareness }\end{array}$ & offers & $\begin{array}{l}\text { Count of } \\
\text { Awareness }\end{array}$ & Product and offers $\begin{array}{l}\% \text { of Product and offers } \\
\text { Awareness }\end{array}$ & $\begin{array}{l}\text { Tot } \\
\text { al }\end{array}$ \\
\hline Regular visit & & 67 & & $78.30 \%$ & \\
Procuress & & 11 & & & $7.60 \%$ & \\
Social Media & & 22 & & & $15 \%$ & 100 \\
\hline
\end{tabular}

The survey found that most of the customers know about the offers and products of MegaMart by a regular visit by $78.3 \%$.

Relationship Between Independent Variables and Dependent Variables

In this section, the relationship between independent variables and dependent variables was shown. The dependent 
variable was Customer Relationship Management (CRM), and the independent variables were communication, loyalty, and attitude.

Table 10: Case Processing Summary

\begin{tabular}{|c|c|c|c|}
\hline & & $\mathrm{N}$ & $\%$ \\
\hline \multirow{3}{*}{ Cases } & Valid & 100 & 100.0 \\
\hline & Excluded & 0 & .0 \\
\hline & Total & 100 & 100.0 \\
\hline
\end{tabular}

a. Listwise deletion based on all variables in the procedure.

Table 11: Reliability Statistics

\begin{tabular}{cccc}
\hline \hline & Cronbach's Alpha & $\begin{array}{c}\text { Cronbach's Alpha Based } \\
\text { on Standardized Items }\end{array}$ & N of Items \\
\hline \hline CRM & .956 & .956 & 5 \\
Communication & .951 & .951 & 5 \\
Loyalty & .948 & .948 & 5 \\
Attitude & .931 & .931 & 5 \\
\hline \hline
\end{tabular}

Table 12: Cronbach's Alpha Based on Standardized Items

\begin{tabular}{cccc}
\hline \hline & Cronbach's Alpha & Cronbach's Alpha Based on Standardized Items & N of Items \\
\hline \hline CRM & 0.956 & 0.956 & 5 \\
COM & 0.951 & 0.951 & 5 \\
LOY & 0.948 & 0.948 & 5 \\
ATT & 0.931 & 0.931 & 5 \\
\hline \hline
\end{tabular}

One hundred (100) people were asked to complete the survey, and none of the cases was excluded.

The reliability factor using alpha Cronbach is $95.6 \%$, which was more than $70 \%$, and that made it statically acceptable.

Table 13: Summary Item Statistics

\begin{tabular}{lrrrrrrrr}
\hline \hline & Mean & Minimum & Maximum & Range & $\begin{array}{c}\text { Maximum / } \\
\text { Minimum }\end{array}$ & Variance & N of Items \\
\hline Item Means & 4.850 & 4.833 & 4.867 & 0.033 & 1.007 & 0.000 & 20 \\
Item Variances & 0.129 & 0.118 & 0.141 & 0.024 & 1.202 & 0.000 & 20 \\
\hline \hline
\end{tabular}

The statistical analysis found that most of the correspondents answered with Strongly Agree with a mean of 4.850 with a standard deviation of .343 away from the mean.

Table 14: Scale Statistics

\begin{tabular}{cccc}
\hline \hline Mean & Variance & Std. Deviation & N of Items \\
\hline 97.0000 & 28.136 & 5.30430 & 20 \\
\hline \hline
\end{tabular}

Table 15: Mean Chi-Square (ANOVA with Friedman's Test and Tukey's Test for Nonadditivity)

\begin{tabular}{|c|c|c|c|c|c|c|}
\hline & & & Sum of Squares & $\mathrm{df}$ & Mean Square & Friedman's Chi-Square \\
\hline \multirow{3}{*}{ Between People } & & & 83.000 & 99 & 1.407 & \\
\hline & Between I & ems & .333 & 19 & .018 & 0.282 \\
\hline & & Nonadditivty & $.590^{\mathrm{a}}$ & 1 & .590 & 9.572 \\
\hline \multirow[t]{3}{*}{ Within People } & Residual & Balance & 69.076 & 1120 & .062 & \\
\hline & & Total & 69.667 & 1121 & .062 & \\
\hline & Total & & 70.000 & 1140 & .061 & \\
\hline Total & & & 153.000 & 1199 & .128 & \\
\hline
\end{tabular}

We concluded that the mean CRM is significantly different for at least one of the customer group (F2, 83= 9.572, $\mathrm{p}<0.282$ ). Considered that the ANOVA did not tell us specifically which Means were different from one another.

To determine, we needed to follow up with multiple comparisons (or post-hoc) tests. 
Table 16: Significant (ANOVA with Friedman's Test and Tukey's Test for Nonadditivity)

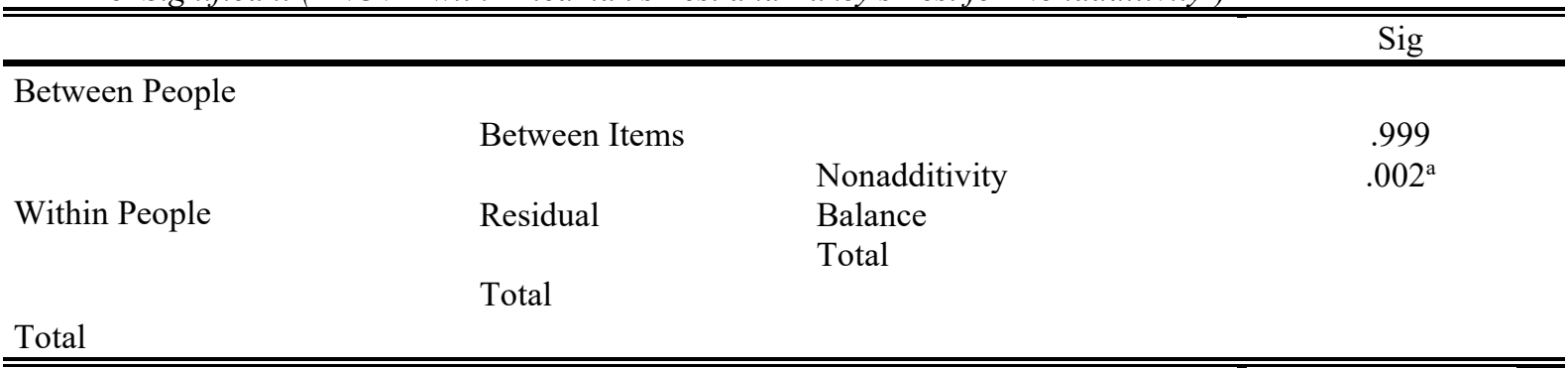

Grand Mean $=4.8500$

The analysis showed that the Mean was significant, around .999 , with a significant level of .002, which was more than $5 \%$.

Table 17: ANOVA

\begin{tabular}{|c|c|c|c|c|c|c|}
\hline & & Sum of df Squares & & Mean Square & $\mathrm{F}$ & Sig. \\
\hline \multirow{3}{*}{$\mathrm{COM}$} & Between Groups & 107.936 & 7 & 15.419 & 1.236 & .21 \\
\hline & Within Groups & .000 & 1 & .000 & & \\
\hline & Total & 107.936 & 8 & & & \\
\hline \multirow{3}{*}{ LOY } & Between Groups & 1.484 & 7 & .212 & .158 & .05 \\
\hline & Within Groups & 1.345 & 1 & 1.345 & & \\
\hline & Total & 2.829 & 8 & & & \\
\hline \multirow{3}{*}{ ATT } & Between Groups & .036 & 6 & .006 & .185 & .00 \\
\hline & Within Groups & .032 & 1 & .032 & & \\
\hline & Total & .068 & 7 & & & \\
\hline
\end{tabular}

Table 18: Descriptive Statistics Customer Relationship Management (CRM)

\begin{tabular}{lccc}
\hline \hline & $\mathrm{N}$ & Mean & Std. Deviation \\
\hline A1 & 100 & 4.8667 & .34280 \\
A2 & 100 & 4.8333 & .37582 \\
A3 & 100 & 4.8333 & .37582 \\
A4 & 100 & 4.8667 & .34280 \\
A5 & 100 & 4.8667 & .34280 \\
Valid N (listwise) & 100 & & \\
\hline
\end{tabular}

1. The statistical analysis found that most of the correspondents found that MegaMart treated customers with great care, and they strongly agreed with a mean answer of 4.8667 with a standard deviation of .34280 away from the mean.

2. The statistical analysis found that most of the correspondents found that efforts are made by employees to make the customer delighted, and they strongly agreed with a mean answer of 4.8333 with a standard deviation of .37582 away from the mean.

3. The statistical analysis found that most of the correspondents found that Mega Mart treated its customers with respect, and they strongly agreed with a mean answer of 4.8333 with a standard deviation of .37582 away from the mean.

4. The statistical analysis found that most of the correspondents found that Mega Mart offered convenience to its customers, and they strongly agreed with a mean answer of 4.8667with a standard deviation of.34280 away from the mean.

5. The statistical analysis found that most of the correspondents found that Mega

Mart solved problems efficiently, and they strongly agreed with a mean answer of 4.8667 with a standard deviation of .34280 away from the mean. 
Table 19: Descriptive Statistics Communication

\begin{tabular}{lccc}
\hline \hline & $\mathrm{N}$ & Mean & Std. Deviation \\
\hline B1 & 100 & 4.8333 & .37582 \\
B2 & 100 & 4.8333 & .37582 \\
B3 & 100 & 4.8667 & .34280 \\
B4 & 100 & 4.8667 & .34280 \\
B5 & 100 & 4.8333 & .37582 \\
Valid N (listwise) & 100 & & \\
\hline \hline
\end{tabular}

1. The statistical analysis found that most of the correspondents found that MegaMart encouraged interaction among its customers, and they strongly agreed with a mean answer of 4.8333 with a standard deviation of .37582 away from the mean.

2. The statistical analysis found that most of the correspondents found that MegaMart communicated channels for complaints and suggestions, and they strongly agreed with a mean answer of 4.8333 with a standard deviation of .37582 away from the mean.

3. The statistical analysis found that most of the correspondents found that MegaMart tried to get to know their preferences, questions, and suggestions. They strongly agreed with a mean answer of 4.8667 with a standard deviation of .34280 away from the mean.

4. The statistical analysis found that most of the correspondents found that MegaMart staff was competent in handling customer concerns. They strongly agreed with a mean answer of 4.8667 with a standard deviation of .34280 away from the mean.

5. The statistical analysis found that most of the correspondents found that MegaMart had the right virtual, and they strongly agreed with a mean answer of 4.8333 with a standard deviation of .37582 away from the mean.

Table 20: Descriptive Statistics Loyalty

\begin{tabular}{lccc}
\hline \hline & $\mathrm{N}$ & Mean & Std. Deviation \\
\hline C1 & 100 & 4.8333 & .37582 \\
C2 & 100 & 4.8667 & .34280 \\
C3 & 100 & 4.8667 & .34280 \\
C4 & 100 & 4.8333 & .37582 \\
C5 & 100 & 4.8333 & .37582 \\
Valid N (listwise) & 100 & & \\
\hline \hline
\end{tabular}

1. The statistical analysis found that most of the correspondents found that they felt they were loyal to MegaMart brand/offerings. They strongly agreed with a mean answer of 4.8333 with a standard deviation of .37582 away from the mean.

2. The statistical analysis found that most of the correspondents found that even when they heard negative information about MegaMart, they still stick with MegaMart, and they strongly agreed with a mean answer of 4.8667 with a standard deviation of .34280 away from the mean.

3. The statistical analysis found that most of the correspondents found that even with more choices, they did not choose other brands/offerings. They strongly agreed with a mean answer of 4.8667 with a standard deviation of .34280 away from the mean.

4. The statistical analysis found that most of the correspondents found their continued association with MegaMart was essential. They strongly agreed with a mean answer of 4.8333 with a standard deviation of .34280 away from the mean.

5. The statistical analysis found that most of the correspondents found if they had been asked to change to another supermarket, they chose and promote MegaMart. They strongly agreed with a mean answer of 4.8333 with a standard deviation of .34280 away from the mean.

Table 21: Descriptive Statistics Attitude

\begin{tabular}{lrrr}
\hline \hline & $\mathrm{N}$ & $\mathrm{M}$ & Std. Deviation \\
\hline D1 & 100 & 4.8667 & .34280 \\
D2 & 100 & 4.8667 & .34280 \\
D3 & 100 & 4.8333 & .37582 \\
D4 & 100 & 4.8333 & .37582 \\
D5 & 100 & 4.8667 & .34280 \\
Valid N (listwise) & 100 & & \\
\hline \hline
\end{tabular}

1. The statistical analysis found that most of the correspondents found that they felt good when they enter MegaMart. They strongly agreed with a mean answer of 4.8667 with a standard deviation of .34280 away from the mean.

2. The statistical analysis found that most of the correspondents found that their shopping experiences with 
MegaMart were better than they expected. They strongly agreed with a mean answer of 4.8667 with a standard deviation of .34280 away from the mean.

3. The statistical analysis found that most of the correspondents found that they would try new services and products that were provided by MegaMart. They strongly agreed with a mean answer of 4.8333 with a standard deviation of .37582 away from the mean.

4. The statistical analysis found that most of the correspondents found that they recommended other people to patronize MegaMart. They strongly agreed with a mean answer of 4.8333 with a standard deviation of .37582 away from the mean.

5. The statistical analysis found that most of the correspondents found that they said positive things to other people about the services provided in MegaMart, and they strongly agreed with a mean answer of 4.8667 with a standard deviation of .34280 away from the mean.

Table 22: Model Summary

\begin{tabular}{|c|c|c|c|c|c|c|c|c|c|}
\hline \multirow[t]{2}{*}{ Model } & \multirow[t]{2}{*}{$\mathrm{R}$} & \multirow{2}{*}{$\begin{array}{l}\mathrm{R} \\
\text { Square }\end{array}$} & \multirow{2}{*}{$\begin{array}{l}\text { Adjusted } \\
\text { R Square }\end{array}$} & \multirow{2}{*}{$\begin{array}{l}\text { Std. The } \\
\text { error of the } \\
\text { Estimate }\end{array}$} & \multicolumn{4}{|c|}{ Change Statistics } & \multirow{2}{*}{$\begin{array}{l}\text { Durbin- } \\
\text { Watson }\end{array}$} \\
\hline & & & & & $\begin{array}{l}\mathrm{R} \text { Square } \\
\text { Change }\end{array}$ & F Change & df1 df2 & $\begin{array}{l}\text { Sig.F } \\
\text { Change }\end{array}$ & \\
\hline 1 & .919 & .845 & .826 & .11328 & .845 & 1920575 & 96 & .000 & .901 \\
\hline
\end{tabular}

First, the auto-correlation was tested using the Durbin Watson test of the supercar, not tested before, so Lag1 was used and excluded.

Secondly, the analysis between the independent variables and the CRM was $91.9 \%$, with R2 being set in the region that was $82.2 \%$, which means that $82.6 \%$ of the variation in CRM can be explained by it.

Table 23: NNOVA $^{\mathrm{a}}$

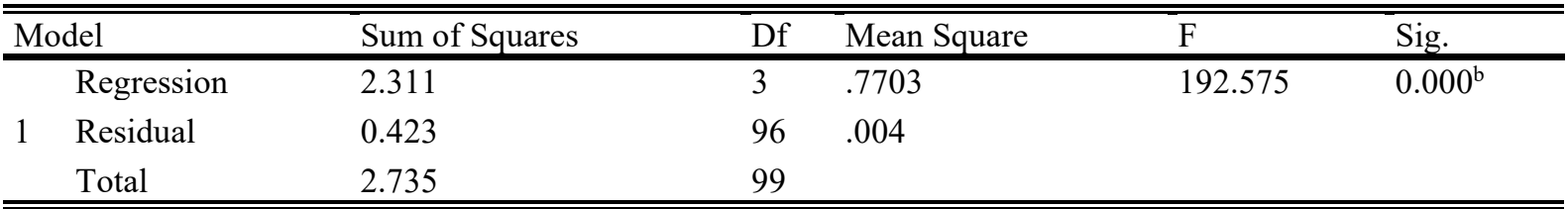

The ANOVA test showed the quality of the model at $0 \%$, which was significant at P-Value at $5 \%$.[[[ Table 24: Unstandardized Coefficients

\begin{tabular}{|c|c|c|c|c|c|c|c|c|}
\hline \multirow[t]{2}{*}{ Model } & \multicolumn{2}{|c|}{$\begin{array}{l}\text { Unstandardized } \\
\text { Coefficients }\end{array}$} & \multirow[t]{2}{*}{$\overline{\mathrm{T}}$} & \multirow[t]{2}{*}{ Sig. } & \multicolumn{4}{|c|}{$\begin{array}{l}95.0 \% \\
\text { Interval for } \mathrm{B} \\
\end{array}$} \\
\hline & B & Std. Error & & & $\begin{array}{l}\text { Lower } \\
\text { Bound }\end{array}$ & $\begin{array}{l}\text { Upper } \\
\text { Bound }\end{array}$ & Tolerance & VIF \\
\hline \multirow{4}{*}{$\begin{array}{l}\text { (Constant) } \\
\text { COM } \\
\text { LOY } \\
\text { ATT }\end{array}$} & .830 & .106 & 7.820 & .000 & .614 & 1.046 & & \\
\hline & .002 & .001 & 2.826 & .008 & -.004 & -.001 & .416 & 2.401 \\
\hline & 3.738 & .000 & 3.552 & .001 & .000 & .000 & .208 & 4.810 \\
\hline & -.027 & .013 & 1.993 & .005 & -.054 & .001 & .307 & 3.257 \\
\hline
\end{tabular}

Thirdly, Collinearity was tested to test while the correlation of independent variables within the correlation equation was not high by first testing the VIF, which did not exceed ten to ensure the quality of the test and was actually within the acceptable level. Secondly, the Tolerance, which was higher than $20 \%$ to ensure the quality of the test, was also within the required level.

Fourth, the regression equation was formulated as follows:

$\mathrm{CRM}=.83+(.002) \mathrm{COM}+(3.738) \mathrm{LOY}+(-.027) \mathrm{ATT}$

Where:

$\mathrm{CRM}=$ Customer Relationship Management

$\mathrm{COM}=$ Communication

LOY=Loyalty

ATT=Attitude

The equation explained that when the CRM increases by one unit, the COM increase by 0.002 points, the LOY by 3.738 unit, and the ATT decreased by $0.027 \%$. The value of alpha was 0.83 .

\section{CONCLUSION, AND RECOMMENDATION}

The study was undertaken to analyze the Customer Relationship Management (CRM) of the communication, loyalty, and attitude on the practices in the MegaMart.

The respondents of the study were consumers of MegaMart in the Kingdom of Bahrain. In the study, the researcher used multiple regression analysis to identify the relationship between the independent variable and the dependent variable. 
The objective of this study was to recognize Customer Relationship Management (CRM) practices, where the researcher identified three practices in the MegaMart. The practices were communication, loyalty, and attitude. Moreover, the study aimed to analyze the relationship between each independent variable along with the dependent variable.

And the research concluded the following:

1. The researcher used the questionnaire to collect the data and multiple regression analyses to identify the connection. The respondents of the survey strongly agreed with the statements in regards to the loyalty, and the highest mean was 4.64 .

2. Moreover, in terms of loyalty, respondents mostly agreed, and the highest mean was 4.94.

3. Meanwhile, in terms of communication, the respondents strongly agreed with the statements, and the highest mean was 4.97. The multiple regression analysis indicated that there was a positive relationship between the independent variables and the dependent variable.

4. The evidence was from the positive signs of the estimated coefficient of the independent variables. The regression analysis indicated that loyalty was the most practices that Customer Relationship Management (CRM) in MegaMart, and it had a beta of 3.738, which was the highest among all factors. Based on the findings, the researcher accepted all the hypotheses.

Based on the questionnaire survey and the results, the following recommendations were proposed:

MegaMart and the supermarket should follow the most effective methods, such as loyalty, to get customer satisfaction.

Analyze Customer Relationship Management (CRM) practices to increase customers. Analysts should take into consideration the most practices in Customer Relationship Management (CRM) in the analysis process, and the analyst must not neglect other practices and all Customer Relationship Management (CRM) practices. Loyalty has a high impact on the MegaMart .Therefore, it is necessary to provide the best goods and services to maintain customers. Moreover, loyalty must not be neglected, the customer prefers the X brand, for example, and insists on acquiring it exclusively and does not accept a substitute. If it is not available at a particular time for some reason, he will search for it and wait for it to arrive, which we call brand loyalty.

Last but not least, a practice assessment is a significant part of Customer Relationship Management (CRM) practices appraisal must be done for each supermarket, using an effective practice assessment method to increase customers. All three factors must be analyzed carefully, and each Customer Relationship Management (CRM) practices must be reviewed intensively. Using this survey of the analysis of the companies and supermarkets can verify Customer Relationship Management (CRM) associated practices, and be able to minimize future losses and make smart decisions.

For researcher that would like to investigate in the same topic, the researcher recommends more variables to be added in the study to investigate if there are more variables that Customer Relationship Management (CRM) practices. Also, the sample size can be increased by adding new skills. Moreover, the study can be conducted in the GCC country to test the similarity of the process used in the region.

\section{References}

Alamgir, M., Nasir, T., Shamsuddoha, M., \& Nedelea, A. (2011). Influence Of Brand Name On Consumer Decision Making A Process - An Empirical Study on Car Buyers. The USV Annals of Economics and Public Administration, 10(2), 142-153.

Abrar ul haq, Jali, M. R. M., \& Islam, G. M. N. (2018a). Assessment of the role of household empowerment in alleviating participatory poverty among rural household of Pakistan. Quality \& Quantity, 52(6), 2795-2814.

Abrar ul haq, M, Jali, M.R.M. (2016). Determinants of Rural Poverty in Pakistan: A Micro Study. Journal Governance and Development (Universiti Utara Malaysia press), 12(2): 53-66.

Abrar ul Haq, M. A, Nawaz, M. A., Mahtab, N., \& Cheema, A. K. H. (2012). Determinants of Wage Growth: An Empirical Analysis of Private Formal Sector in Bahawalpur Division. Business and Economic Research, 2(1).

Abrar ul Haq, M., Akram, F., Ashiq, U., \& Raza, S. (2019b). The employment paradox to improve women's empowerment in Pakistan. Cogent Social Sciences, (just-accepted), 1707005.

Abrar ul haq, M., Jali, M. R. M., \& Islam, G. M. N. (2017a). Empowering rural women in Pakistan: empirical evidence from Southern Punjab. Quality \& Quantity, 51(4), 1777-1787.

Abrar ul haq, M., Jali, M. R. M., \& Islam, G. M. N. (2017b). Decision-Making Ability as a Source of Empowerment Among Rural Women of Pakistan. Global Social Welfare, 4(3), 117-125.

Abrar ul haq, M., Jali, M. R. M., \& Islam, G. M. N. (2019a). Household empowerment as the key to eradicate poverty incidence. Asian Social Work and Policy Review, 13(1), 4-24.

Abrar-ul-Haq, M., Jali, M. R. M., \& Islam, G. M. N. (2015). Factors affecting small and medium enterprises (SMEs) development in Pakistan. American-Eurasian Journal of Agricultural \& Environmental Sciences, 15(4), 546-52.

Abrar-ul-Haq, M., Jali, M. R. M., \& Islam, G. M. N. (2018b). The Development of Household Empowerment 
Index among Rural Household of Pakistan. Pertanika Journal of Social Sciences \& Humanities, 26(2).

Abrar-ul-Haq, M., Jali, R. M., \& Islam, G. N. (2016c). Measuring the socio-economic empowerment of rural households in Pakistan. Journal of Governance and Development, 12(1), 107-122.

Akram F, Abrar ul Haq, M., and Umrani, W. A. (2019). Assessing the Effect of Managerial Power on Firm Performance through the Perceptual Lens of Executive Remuneration. Pertanika Journal of Social Sciences and Humanities (University Putra Malaysia Press) 27 (1): 293 - 309

Akram, F. (2017). Innovation as Mediator between Corporate Governance and Firm Performance: A Theoretical Perspective. International Journal of Innovative Knowledge Concepts, 5(11).

Akram, F., Murugiah, L., \&Arfan, A. (2017). Cultural Aspects and Leadership Effectiveness of Women Leaders: A Theoretical Prospective of Saudi Arabia. Pakistan Journal of Humanities and Social Sciences, 5(1).

Alessandro Inversini, Roland Schegg. (2016). Information and Communication Technologies in Tourism: Proceedings of the International. (pp. 314)

As, S. \& Mishra, M. (2019). The Impact of Customer Relationship Management (CRM) Practices on Customer Satisfaction. Business Governance and Society (pp. 43-54). Palgrave Macmillan, Cham.

Ashraf, S., Abrar-ul-Haq, M., \& Ashraf, S. (2017). Domestic Violence against Women: Empirical Evidence from Pakistan. Pertanika Journal of Social Sciences \& Humanities, 25(3), 1401-1418.

Asquith, C. R., Laitinen, T., Konstantinova, L. S., Tizzard, G., Poso, A., Rakitin, O. A., ... \& Hilton, S. T. (2019). Investigation of the Pentathiepin Functionality as an Inhibitor of Feline Immunodeficiency Virus (FIV) via a Potential Zinc Ejection Mechanism, as a Model for HIV Infection. ChemMedChem, 14(4), 454-461.

Baltic Journal of Management Jerry Fjermestad, Nicholas C Robertson Jr.( 2015). Electronic Customer Relationship Management. Advances in Management Information Systems. 3rd Edition (pp.88)

Budianto, A. (2019). Customer Loyalty: Quality of Service. Journal of Management Review, 3(1), $299-305$.

Cassandra France, Bill Merrilees, Dale Miller, (2015), "Customer brand-creation: a conceptual. Model", Marketing Intelligence \& Planning, Vol. 33 Iss 6 pp. $848-864$

Chidester, T. R., \& Anca, J. (2019). Crew Resource Management, Risk, and Safety Management Systems. In Crew Resource Management (pp. 227-247). Academic Press.

Chidester, T. R., Kanki, B. G., \& Anca Jr, J. M. (2019). The Future of CRM. In Crew Resource Management (pp. 581-585). Academic Press.

Clauss, T., Kesting, T., \& Naskrent, J. (2019). A Rolling Stone Gathers No Moss: The Effect of Customers' Perceived Business Model Innovativeness on Customer Value Co-Creation Behavior and Customer Satisfaction In The Service Sector. R\&D Management, 49(2), 180-203.

De Juan-Jordán, H., Guijarro-García, M., \& Gadea, J. H. (2018). Feature Analysis of the "Customer Relationship Management" Systems for Higher Education Institutions. Multidisciplinary Journal for Education, Social and Technological Sciences, 5(1), 30-43.

Dewnarain, S., Ramkissoon, H., \& Mavondo, F. (2019). Social Customer Relationship Management: An Integrated Conceptual Framework. Journal of Hospitality Marketing \& Management, 28(2), 172-188.

Eastman, J. K., Smalley, K. B., \& Warren, J. C. (2019). The Impact Of Cause-Related Marketing on Millennials' Product Attitudes And Purchase Intentions. Journal Of Promotion Management, 25(6), 799-826.

Francis Buttle, Stan Maklan (2015). Customer Relationship Management: Concepts and Technologies. is a Reader in Strategic Marketing, Cranfield School of Management, 3rd Edition (pp 11)

Greve, G., \&Schlüschen, A. (2018). From Customer Relationship Management to Influencer Relationship Management. In Diverse Methods in Customer Relationship Marketing and Management (pp. 80-91). IGI Global.

Hargie, O. (2018). Skill in Theory: Communication as Skilled Performance. In The Handbook of Communication Skills (pp. 9-40). Routledge.

Hill, N., \& Alexander, J. (2017). The Handbook of Customer Satisfaction and Loyalty Measurement. Routledge.

Kanki, B. G., Anca, J., \& Chidester, T. R. (Eds.). (2019). Crew Resource Management. Academic Press.

Kasemsap, K. (2019). Facilitating Customer Relationship Management in Modern Business. In Advanced Methodologies and Technologies in Digital Marketing and Entrepreneurship (pp. 44-56). IGI Global.

Khan, R. E. A., Rehman, H., \& Haq, M. A. (2015). Determinants of rural household poverty: the role of household socioeconomic empowerment. American-Eurasian J. Agric. \& Environ. Sci, 15(1), 93-98.

Lawrence, J. M., Crecelius, A. T., Scheer, L. K., \& Patil, A. (2019). Multichannel Strategies for Managing the Profitability of Business-to-Business Customers. Journal of Marketing Research, 56(3), 479-497.

Lee, In (2018). Diverse Methods in Customer Relationship Marketing and Management. Advances in Marketing, Customer Relationship Management, and E-Services (2327-5502) IGI Global (pp. 44-81-215)

Liu, J., Lozano-Perez, S., Karamched, P., Holter, J., Wilkinson, A. J., \& Grovenor, C. R. (2019). Forescattered Electron Imaging of Nanoparticles in a Scanning Electron Microscopy. arXiv preprint arXiv:1904.05660.

Malik, H. A. M., Abid, F., Gilal, A. R., \& Raja, A. S. (2017c). Use of cloud computing in Hajj crowed management and complex systems. In 2017 4th IEEE International Conference on Engineering Technologies and Applied 
Sciences (ICETAS) (pp. 1-5). IEEE.

Malik, H. A. M., Abid, F., Kalaicelvi, R., \& Bhatti, Z. (2018). Challenges of Computer Science and IT in TeachingLearning in Saudi Arabia. Sukkur IBA Journal of Computing and Mathematical Sciences, 2(1), 29-35.

Malik, H. A. M., Abid, F., Mahmood, N., Wahiddin, M. R., \& Malik, A. (2019a). Nature of Complex Network of Dengue Epidemic as a Scale-Free Network. Healthcare Informatics Research, 25(3), 182-192.

Malik, H. A. M., Abid, F., Wahiddin, M. R., \& Bhatti, Z. (2017a). Robustness of dengue complex network under targeted versus random attack. Complexity, 2017.

Malik, H. A. M., Mahesar, A. W., Abid, F., \& Wahiddin, M. R. (2014, November). Two-mode complex network modeling of dengue epidemic in Selangor, Malaysia. In The 5th International Conference on Information and Communication Technology for The Muslim World (ICT4M) (pp. 1-6). IEEE.

Malik, H. A. M., Mahesar, A. W., Abid, F., Waqas, A., \& Wahiddin, M. R. (2017b). Two-mode network modeling and analysis of dengue epidemic behavior in Gombak, Malaysia. Applied Mathematical Modelling, 43, $207-$ 220

Malik, H. A. M., Mahmood, N., Usman, M. H., \& Abid, F. (2019b). Un-weighted Network Study of Pakistani Airports. In 2019 2nd International Conference on Computing, Mathematics and Engineering Technologies (iCoMET) (pp. 1-6). IEEE.

Malik, H. A. M., Mahmood, N., Usman, M. H., Rziwan, K., \& Abid, F. (2019c). Analysis of Airport Network in Pakistan Utilizing Complex Network Approach. network, 10(1).

Mason, J. P., \&Bobra, M. (2019, June). HelioML: An interactive Online Book at the Crossroads of Heliophysics and Machine Learning Containing the Code Behind Published Papers. In American Astronomical Society Meeting Abstracts (Vol. 234).

Mauro, D. A., \& Raman, V. R. (2018). U.S. Patent No. 9,992,334. Washington, DC: U.S. Patent and Trademark Office.

Mehtab, N., Khan, T. \& Abrar ul haq, M. (2012). Gender disparity in economic returns to higher education: evidence from private formal sector of Bahawalpur (Pakistan).

Myers, S. R., \& Donoghue, A. J. (2019). Quality Improvement and Crisis Resource Management in Pediatric Resuscitation. Current Opinion in Pediatrics, 31(3), 297-305.

N'Goala, G., Pez-Perard, V., \& Prim-Allaz, I. (Eds.). (2019). Augmented Customer Strategy: CRM in the Digital Age. John

Nguyen, B., Simkin, L., \& Canhoto, A. I. (Eds.). (2015). The Dark Side of CRM: Customers, Relationships, and Management. Routledge., (pp: 201)

Qamri, G. M., Haq, M. A. U., \& Akram, F. (2015). The Impact of Inflation on Stock Prices: Evidence from Pakistan.

Qasim, M., Haq, M. A. U., Hussain, T., \& Roshan, C. (2018). Does Women Well-being Matter for Demand and Development of Children?. Ekoist: Journal of Econometrics and Statistics, 14(29), 169-197.

Raza, S., Minai, M. S., ul Haq, M. A., Ismail, A. I., \& Zain, A. Y. M. (2018). Entrepreneurial Network Towards Small Firm Performance through Dynamic Capabilities: The Conceptual Perspective. Academy of Entrepreneurship Journal, 24(4), 1-9.

Skoumpopoulou, D., \& Franklin, B. (2019). Implementing a Customer Relationship Management (CRM) System. In Advanced Methodologies and Technologies in Digital Marketing and Entrepreneurship (pp. 57-69). IGI Global.

Snieckus, V., \& da Frota, L. C. (2019). Spiroindolines by Visible-Light-Mediated Intramolecular Cycloadditions. Synfacts, 15(04), 0355.

Tartaglione, A. M., Cavacece, Y., Russo, G., \& Granata, G. (2019). A Systematic Mapping Study on Customer Loyalty and Brand Management. Administrative Sciences, 9(1).

Ullah, S., Abrar-ul-haq, M., \& Shah, S. W. A. (2016). Governance And Exchange Rate In Pakistan: A Time Series Analysis. Science International, 28(1).

Van Gammeren, A. J., van den Bos, A. G., Som, N., Veldhoven, C., Vossen, R. C., \& Folman, C. C. (2019). A National Transfusion Register of Irregular Antibodies and Cross (X)-match Problems: TRIX, A 10-year Analysis. Transfusion

Vukšić, V. B., Bach, M. P., Garrido-Moreno, A., Lockett, N., \& Garcia-Morales, V. (2015). Exploring the Role of Knowledge Management Practices in Fostering Customer Relationship Management as a Catalyst for Marketing Innovation.

Wayne D. Hoyer, Deborah J. MacInnis, Rik Pieters (2016) s.370-01(pp33)

Wiley \& Sons. N'Goala, G., Pez-Perard, V., \& Prim-Allaz, I. (Eds.). (2019). Augmented Customer Strategy: CRM in the Digital Age. John Wiley \& Sons. 
General Data

APPENDIX : QUESTIONNAIRE

\begin{tabular}{|c|c|}
\hline Gender & $\begin{array}{ll}\circ & \text { Male } \\
\circ & \text { Female }\end{array}$ \\
\hline Age of the Respondent & $\begin{array}{ll} & 16-19 \\
\circ & 20-29 \\
\circ & 30-39 \\
\circ & 40-49 \\
\circ & 50 \text { and above }\end{array}$ \\
\hline Education Level & $\begin{array}{ll}\circ & \text { High school diploma } \\
\circ & \text { Bachelor's Degree } \\
\circ & \text { Master's Degree } \\
\circ & \text { PhD } \\
\end{array}$ \\
\hline $\begin{array}{l}\text { What do you purchase mostly from } \\
\text { Mega Mart }\end{array}$ & $\begin{array}{ll}\circ & \text { Food } \\
\circ & \text { Non-Food }\end{array}$ \\
\hline $\begin{array}{l}\text { How many times you shop in Mega } \\
\text { Mart }\end{array}$ & $\begin{array}{ll}\circ & \text { Weekly } \\
\circ & \text { Monthly } \\
\circ & \text { Yearly } \\
\circ & \text { Rarely }\end{array}$ \\
\hline $\begin{array}{l}\text { How you know about Mega Mart } \\
\text { products and offers }\end{array}$ & $\begin{array}{ll}\circ & \text { Regular visit } \\
\circ & \text { Social Media }\end{array}$ \\
\hline $\begin{array}{l}\text { How much you spend in Mega } \\
\text { Mart per visit }\end{array}$ & $\begin{array}{ll} & \text { Less than 10BD } \\
\circ & 10-20 \mathrm{BD} \\
\circ & 20-50 \mathrm{BD} \\
\circ & 50-100 \mathrm{BD} \\
\circ & 100 \mathrm{BD} \text { and above } \\
\end{array}$ \\
\hline
\end{tabular}

\section{PART I}

Below are given some statements that measure the Communication, Loyalty, and Attitude in Customer Relationship Management (CRM) Practices.

Kindly Circle Your Agreement Level in A 5-Point Scale, where 5 Stands for Strongly Agree, 4 Agree, 3 Neutral,2 Disagree, and 1 Strongly Disagree. There is no right or wrong answer; just state your opinion.

\begin{tabular}{|c|c|c|c|c|c|c|}
\hline & COMMUNICATION & $\begin{array}{l}\text { Strongly } \\
\text { agree } \\
5 \\
\end{array}$ & $\begin{array}{c}\text { Agree } \\
4 \\
\end{array}$ & $\begin{array}{c}\text { Neutral } \\
3 \\
\end{array}$ & $\begin{array}{l}\text { Disagree } \\
2 \\
\end{array}$ & $\begin{array}{l}\text { Strongly } \\
\text { disagree } \\
1 \\
\end{array}$ \\
\hline 1 & $\begin{array}{l}\text { Mega Mart encourages interaction among its } \\
\text { customers (e.g., events, Facebook, etc.) }\end{array}$ & & & & & \\
\hline 2 & $\begin{array}{l}\text { Mega Mart has communication channels for } \\
\text { complaints and suggestions (e.g., toll-free, } \\
\text { online customer service, etc.). }\end{array}$ & & & & & \\
\hline 3 & $\begin{array}{l}\text { Mega Mart tries to get to know my preferences, } \\
\text { questions, and suggestions. }\end{array}$ & & & & & \\
\hline 4 & $\begin{array}{l}\text { Our staff is competent in handling customer } \\
\text { concerns. }\end{array}$ & & & & & \\
\hline 5 & $\begin{array}{l}\text { Mega Mart has the right virtual, in case of } \\
\text { websites). }\end{array}$ & & & & & \\
\hline & LOYALTY & $\begin{array}{l}\text { Strongly } \\
\text { agree } \\
5 \\
\end{array}$ & $\begin{array}{c}\text { Agree } \\
4 \\
\end{array}$ & $\begin{array}{c}\text { Neutral } \\
3 \\
\end{array}$ & $\begin{array}{c}\text { Disagree } \\
2 \\
\end{array}$ & $\begin{array}{l}\text { Strongly } \\
\text { disagree } \\
1 \\
\end{array}$ \\
\hline 1 & I feel I am loyal to Mega Mart's brand/offerings. & & & & & \\
\hline 2 & $\begin{array}{l}\text { Even when I hear negative information about } \\
\text { Mega Mart, I still stick with Mega Mart. }\end{array}$ & & & & & \\
\hline 3 & $\begin{array}{l}\text { Even with more choices, I will not choose other } \\
\text { brands/offerings. }\end{array}$ & & & & & \\
\hline 4 & $\begin{array}{l}\text { My continued association with Mega Mart is } \\
\text { essential to me. }\end{array}$ & & & & & \\
\hline 5 & $\begin{array}{l}\text { if I have been asked to change to another supermarket, } \\
\text { I would still choose and promote MegaMart. }\end{array}$ & & & & & \\
\hline
\end{tabular}




\begin{tabular}{|c|l|l|l|l|l|l|}
\hline & ATTITUDE & $\begin{array}{l}\text { Strongly } \\
\text { agree } \\
\mathbf{5}\end{array}$ & $\mathbf{A g r e e}$ & Neutral & Disagree & $\begin{array}{l}\text { Strongly } \\
\text { disagree } \\
\mathbf{1}\end{array}$ \\
\hline 1 & I feel good when I enter Mega Mart. & $\mathbf{3}$ & $\mathbf{2}$ & & & \\
\hline 2 & $\begin{array}{l}\text { My shopping experiences with Mega Mart are } \\
\text { better than I expected. }\end{array}$ & $\begin{array}{l}\text { I will try new services and products that are } \\
\text { provided by Mega Mart. }\end{array}$ & & & & \\
\hline 4 & $\begin{array}{l}\text { I will recommend other people to patronize to } \\
\text { Mega Mart. }\end{array}$ & & & & \\
\hline 5 & $\begin{array}{l}\text { I will say positive things to other people about } \\
\text { the services provided in Mega Mart. }\end{array}$ & & & & \\
\hline
\end{tabular}

\section{PART II}

Below are provided statement measures the Customer Relationship Management (CRM) Practices kindly circle your agreement level in a 5-point scale, where 5 stands for strongly agree, 4 agree, 3 Neutral, 2 disagree, and 1 strongly disagree. There is no definite answer; state your opinion.

\begin{tabular}{|l|l|c|c|c|c|}
\hline & $\begin{array}{l}\text { Customer Relationship Management } \\
\text { Practices }\end{array}$ & $\begin{array}{c}\text { Strongly } \\
\text { agree } \\
\mathbf{5}\end{array}$ & $\begin{array}{c}\text { Agree } \\
\text { (All people in my Mega Mart treat customers with } \\
\text { great care. }\end{array}$ & $\begin{array}{l}\text { Neutral } \\
\text { Disagree }\end{array}$ & $\begin{array}{l}\text { Strongly } \\
\text { disagree } \\
\mathbf{1}\end{array}$ \\
\hline 2 & $\begin{array}{l}\text { Efforts are made by employees to make the } \\
\text { customer delighted. }\end{array}$ & & & & \\
\hline 3 & Mega Mart treats its customers with respect. & & & & \\
\hline 4 & $\begin{array}{l}\text { Mega Mart offers convenience to its customers } \\
\text { (e.g., online services, home delivery, 24-7 } \\
\text { customer service) }\end{array}$ & & & \\
\hline 5 & Mega Mart solves problems efficiently. & & & & \\
\hline
\end{tabular}

